\title{
Frequent $\beta$-catenin overexpression without exon 3 mutation in cutaneous lymphomas
}

\author{
Barbara Bellei, Alberto Pacchiarotti, Marie Perez and Tullio Faraggiana \\ Laboratory of Histopathology, Istituto Dermopatico dell'Immacolata-Istituto di Ricovero e Cura a Carattere \\ Scientifico (IDI-IRCCS), Rome, Italy
}

\begin{abstract}
$\beta$-Catenin is a ubiquitously cytoplasmic protein that has a critical role in embryonic development and mature tissue homeostasis through its effects on E-cadherin-mediated cell adhesion and Wnt-dependent signal transduction. Mutations that alter specific $\beta$-catenin residues important for GSK-3 $\beta$ phosphorylation, or increase the half-life of the protein, were identified in human cancer. However, the role of the Wnt pathway in $B-$ and T-cell oncogenesis has not been extensively investigated. To assess the role of $\beta$-catenin defects in primary cutaneous lymphomas, we examined the expression pattern and the genetic alteration of $\beta$-catenin on 79 samples from 74 patients with primary cutaneous lymphomas from B- and T-cell origin. Immunohistochemical analysis revealed $\beta$-catenin deregulation in five primary cutaneous B-cell lymphomas (21\%) and in 21 primary cutaneous T-cell lymphomas (42\%) without nuclear accumulation suggesting that activation and accumulation of $\beta$-catenin may play an important role in the development of skin lymphomas. Mutation analysis of $\beta$-catenin exon 3, which included the responsible element for Wnt signaling, was therefore done in 19 samples. However, genetic alterations of $\beta$-catenin exon 3 were not detected in any of these cases suggesting that other regulatory mechanisms may be relevant in activating $\beta$-catenin signaling in cutaneous lymphomas. Modern Pathology (2004) 17, 1275-1281, advance online publication, 11 June 2004; doi:10.1038/modpathol.3800181
\end{abstract}

Keywords: cutaneous lymphomas; $\beta$-catenin; immunohistochemistry; PCR-SSCP; mutations

Primary cutaneous lymphomas comprise a spectrum of diseases characterized by infiltration of the skin by malignant lymphocytes. The clinical manifestations of cutaneous lymphomas vary and can mimic benign. ${ }^{1}$ Cutaneous T-cell lymphomas include mycosis fungoides, Sézary syndrome, lymphomatoid papulosis, CD30 + large cell lymphoma and adult T-cell leukemia/lymphoma. Primary cutaneous B-cell lymphomas are less common than Tcell lymphomas and account for less than $20 \%$ of all primary cutaneous non-Hodgkin's lymphomas and are classified according to their cell of origin. ${ }^{2}$ The precise mechanisms of lymphoma genesis are still obscure. It appears that various factors are involved including environmental, infectious agents, chromosomal translocations, insertions, or point mutations resulting from genetic instability of tumor cells. ${ }^{3}$ The microenvironment in the skin contributes to the peculiar behavior of these neoplasms by

Correspondence: Dr B Bellei, PhD, Laboratory of Histopathology, Istituto Dermopatico dell'Immacolata, Via Monti di Creta 104, 00167 Rome, Italy.

E-mail: b.bellei@libero.it

Received 23 February 2004; revised and accepted 7 April 2004; published online 11 June 2004 providing various signals from adhesion molecules and cytokines.

$\beta$-Catenin is a multifunctional protein that acts as a component of the homotypic cell-cell adhesion apparatus and as a coactivator of the transcription of T-cell transcription factor/lymphoid enhancer binding factor (TCF/LEF) target genes. In the epithelial cells, $\beta$-catenin is localized in the cytoskeletal complex that regulates cell-cell adhesion. ${ }^{4,5}$ Further, $\beta$-catenin is a critical member of the Wnt signaling pathway, which plays an important role in embryonic development and tumorigenesis. ${ }^{6,7}$

Without stimulation, $\beta$-catenin is degraded by the ubiquitin-proteosome pathway, which depends upon $\beta$-catenin phosphorylation. The current model suggests that Axin and APC serve as scaffolds to facilitate the phosphorylation of $\beta$-catenin by GSK$3 \beta$ at several specific serine and threonine residues encoded by exon 3 . Phosphorylated $\beta$-catenin, but not the unphosphorylated form, is rapidly degraded by the ubiquitin-proteosome degradation complex. ${ }^{8}$ Hence, because Wnt activation inhibits the GSK-3 $\beta$ activity, Wnt activation promotes accumulation of the unphosphorylated $\beta$-catenin molecule in the cytoplasm. ${ }^{9}$ Subsequently, free cytoplasmic $\beta$-catenin enters the nucleus, forms a complex with members of T-cell factor/lymphoid enhancer factor 
(TCF/LEF) family of transcription factors, and upregulates the expression of target genes. ${ }^{10,11}$ Recently many important genes, including c-myc, cyclin D1 and matrilysin (matrix metalloproteinase7), which are involved in oncogenesis have been identified as target genes for $\beta$-catenin/Tcf-induced transcription. ${ }^{12-14}$ Several studies have also shown that $\beta$-catenin can be oncogenically activated by direct genetic mutation of the phosphorylation sites in exon 3 , by the inactivation of GSK-3 $\beta$, Axin and APC or by the activation of Wnt signaling pathways. ${ }^{15-17}$

Recently, Wnt family members have been demonstrated to contribute to lymphopoiesis at early stages of both B- and T-cell development. In fact, Wnt signaling through $\beta$-catenin has a positive role in the control of T-cell development, such that an absence or reduction in the Wnt signal leads to a reduction in cell proliferation rate and differentiation to the $\mathrm{CD}^{+}{ }^{+} \mathrm{CD}^{+}$double-positive stage, whereas increased Wnt signaling through stabilization of $\beta$-catenin enables differentiation of thymocytes in the absence of a pre-TCR signal. ${ }^{18-20}$

The role of the Wnt pathway in B- and T-cell oncogenesis has not been extensively investigated. $\beta$-Catenin is not detectable in normal peripheral blood $\mathrm{T}$ cells but is expressed in Jurkat cells, in several other leukemic cell lines and in the human T-cell lymphoma/leukemia cell line Hut102 derived from a patient with cutaneous T-cell lymphoma. ${ }^{21,22}$

In this work, in order to increase our understanding of the molecular mechanisms underlying the development of cutaneous lymphomas, we investigated the potential involvement of $\beta$-catenin signaling in human primary cutaneous lymphomas. We determined the presence and the localization of $\beta$-catenin protein, and screened for mutation of $\beta$-catenin exon 3.

\section{Materials and methods}

\section{Patients}

The present study was based on a selection of 74 cases of human primary cutaneous lymphomas (56 men, 18 women) with a median age of 56.7 years (range, 21-91 years) collected from the archives of Istituto Dermopatico dell'Immacolata of Rome. Cases were classified according to REAL classification and included: 35 mycosis fungoides (MF), 10 patients with Sézary Syndrome (SS), three anaplastic large cell lymphoma (ALCL), 1 NK-cell lymphoma, 1 angiocentric T-cell lymphoma (ATCL), 16 large B-cell lymphoma (LBCL), 3 marginal zone B-cell lymphoma (MZBL) and 5 follicular B-cell lymphoma (FL). These cases were characterized immunophenotypically with antibodies against the B-cell markers (CD20 and CD79a), the T-cell markers (CD3, CD45RO) and CD30 (additional immunostaining for CD56 was performed for the diagnosis of NK-cell lymphoma). All cases selected, with the exception of the NK-cell lymphoma case had a monoclonal origin as determined by polymerase chain reaction amplification of TCR-gamma gene. As negative controls 10 non-neoplastic skin biopsies with lymphocyte-rich infiltrates such as non specific dermatitis, psoriasis and eczema were used.

\section{Immunohistochemical Staining of $\beta$-Catenin}

Representative sections from formalin-fixed, paraffinembedded tumor tissue were processed for immunohistochemical staining. Briefly, $3 \mu \mathrm{m}$ sections were deparaffinized in xylene for $20 \mathrm{~min}$ and rehydrated through graded ethanol. Endogenous peroxidase activity was blocked for $10 \mathrm{~min}$ with $3 \%$ hydrogen peroxidase. Sections were heated in $\mathrm{pH} 6.0$ citrate buffer for $8 \mathrm{~min}$ in a microwave at $600 \mathrm{~W}$ to retrieve the antigen. Nonspecific antibody binding was blocked for $10 \mathrm{~min}$ by incubation with protein block serum free (Dako, Santa Barbara, CA, USA). An anti- $\beta$-catenin monoclonal antibody (Zymed) was diluted 1:100 and incubated in a humidity chamber for $2 \mathrm{~h}$. The primary antibody was visualized using an anti-mouse HRP system with AEC as the chromogen (Dako). Sections were then counterstained by hematoxylin. Positive immunoreactivity of keratinocytes was used as an internal positive control. Phosphate-buffered saline instead of the primary antibody was used as a negative control.

Using cytomorphologic criteria, tumor cells were differentiated from smaller reactive cells. Staining intensities were classified semiquantitatively as follows: 4: strong expression $75-100 \%$ of the tumor cells, 3: $50-75 \%, 2: 25-50 \%, 1: 25-10 \%$ and 0 : less than $10 \%$ of the tumor cells.

\section{Polymerase Chain Reaction-Single Strand Conformation Polymorphism (PCR-SSCP) Analysis of $\beta$-Catenin Exon 3}

Based on the immunostaining results of the $\beta$ catenin protein, a total of 19 cases were selected for mutational analysis in the GSK- $\beta$ phosphorylation consensus motif of the $\beta$-catenin gene by PCRSSCP. Genomic DNA was extracted from the same block evaluated for $\beta$-catenin expression. Eight $10 \mu \mathrm{m}$ embedded sections were deparaffinized using two successive washes of xylene, hydrated through $80 \%$ ethanol solution and air-dried. The DNA for PCR amplification was extracted and purified using Dneasy Tissue Kits (Qiagen, Hilden, Germany).

PCR-SSCP analysis for $\beta$-catenin exon 3 was performed using the following primers: forward: $5^{\prime}$-ATGGAACCAGACAGAAAAGC- $3^{\prime}$ and reverse $5^{\prime}$-GCTACTTGTTCTTGAGTGAAG- ${ }^{\prime}$. The amplification product included the coding sequence for GSK- $3 \beta$ phosphorylation consensus region of $\beta$ catenin, which has been found to contain activating mutations. The PCR mixture contained: $1 \mu \mathrm{l}$ of 
genomic DNA as template (100-200 ng), $5 \mu \mathrm{l}$ of $10 \times$ PCR buffer I (Perkin-Elmer), $250 \mu \mathrm{M}$ of each dNTP, 25 pmol of each primer and $2.5 \mathrm{U}$ of AmpliGold Taq (Perkin-Elmer) in a final volume of $50 \mu \mathrm{l}$. The reaction was run in a thermal cycler (GeneAmp ${ }^{\mathrm{TM}}$ PCR System 2400, Applied Biosystems). The PCR conditions were: $6 \mathrm{~min}$ of initial denaturation at $94^{\circ} \mathrm{C}$ and 35 cycles consisting of 1 min of denaturation at $94^{\circ} \mathrm{C}$ followed by $1 \mathrm{~min}$ at $55^{\circ} \mathrm{C}$ annealing step and $1 \mathrm{~min}$ at $72^{\circ} \mathrm{C}$ elongation step. The final 7 min incubation at $72^{\circ} \mathrm{C}$ assured a complete extension of the PCR products. The presence of amplified products were checked by electrophoresis in 1.5\% agarose gel containing $2 \mu \mathrm{g} / \mathrm{ml}$ ethidium bromide in TBE buffer.

Nonradioactive SSCP was performed as follows. Reaction mixtures consisting of $20 \mu \mathrm{l}$ containing $10 \mu \mathrm{l}$ of PCR product (about $0.8 \mu \mathrm{g}$ of DNA), $6 \mu \mathrm{l}$ of $1 \mathrm{M}$ urea and $4 \mu \mathrm{l}$ of loading buffer $(0.25 \mathrm{mg}$ bromophenol blue, $0.25 \%$ xylene cyanol and $2.5 \mathrm{mM}$ EDTA) were heated to $94^{\circ} \mathrm{C}$ for $5 \mathrm{~min}$, chilled on ice and then subjected to electrophoresis in $10 \%$ polyacrylamide (29:1 acrylamide:bisacrylamide) TBE gels containing $20 \mathrm{mM}$ HEPES at $200 \mathrm{~V}$ in $1 \times$ TBE buffer for $2 \mathrm{~h}$ in a cold room maintaining the electrophoretic chamber in an ice bath. Human genomic DNA from a healthy donor was used as a negative control in order to evaluate the mobility pattern of the bands in SSCP analysis. A single base substitution from a melanoma patient was used to establish that a point mutations mobility shift could be detected when mutant DNA comprised as little as $6 \%$ of the total gene copies in a PCR mixture (data not shown). Mutational analysis was performed only in the cases with more than $20 \%$ of positive cells considering the whole amount of cells present in the tissue.

\section{Gel Staining}

Gels were stained with a $0.5 \mu \mathrm{g} / \mathrm{ml}$ solution of ethidium bromide in $1 \times$ TBE buffer for $20 \mathrm{~min}$, and then destained in distilled water for $5 \mathrm{~min}$. Ethidium bromide-stained bands were visualized using a $340 \mathrm{~nm}$ UV-viewing box and photographed.

\section{Statistical Analyses}

To evaluate the statistical correlation between $\beta$ catenin expression and both CD30 and the large cell transformation, Fisher's exact probability test was used. A $P$-value $<0.05$ was considered significant.

\section{Results}

Immunohistochemical Expression of $\beta$-Catenin in Primary Cutaneous Lymphomas

Formalin-fixed, paraffin-embedded tissues from 79 biopsies derived from 74 patients were analyzed by immunohistochemistry for the protein expression of $\beta$-catenin. Immunohistochemical results were graded independently by two investigators according to the location and intensity of the signal. Staining of $\beta$-catenin was considered to be positive when at least $10 \%$ of tumor cells within the whole infiltrate were reactive for $\beta$-catenin antibody.

The results of $\beta$-catenin expression are summarized in Table 1. $\beta$-Catenin-positive staining of tumor cells was detected in five of $24(21 \%)$ cases of B-cell lymphomas, including 3 of $16(19 \%)$ diffuse large Bcells lymphomas, 1 of $3(33 \%)$ marginal cells lymphomas, 1 of $5(20 \%)$ follicular center lymphomas. In T-cells lymphomas we observed $\beta$-catenin accumulation in 21 of $50(42 \%)$ case, including 3 of $3(100 \%)$ anaplastic large cell lymphomas, 11 of 35 $(31 \%)$ mycosis fungoides and 7 of $10(70 \%)$ of Sézary Syndrome. Angiocentric lymphoma and NKcell lymphoma did not show $\beta$-catenin antibody reactivity. The expression pattern observed was always cytoplasmic with a particular distribution in the perinuclear area (Figure 1). In all cases, we observed a dot-like positivity with the exception of one case of Sézary Syndrome patient that had a diffuse cytoplasmic strong positivity with few cells having a dot-like signal.

\section{Correlation between $\beta$-Catenin and CD30 Expression}

CD30 antigen is a characteristic cell surface receptor for activated T-cell and the malignant cells of Hodgkin's disease (HD), anaplastic large cell lymphoma (ALCL), mycosis fungoides (MF) evolving into large cell lymphoma and a few other nonHodgkin's lymphomas. In order to investigate the relationship between $\beta$-catenin accumulation and CD30 expression in T-cell lymphomas, we performed a Fisher's exact probability test. Our results demonstrated that 11 of $14(78 \%)$ CD $30+$ cases exhibited staining for $\beta$-catenin, whereas only 10 of $36(27.7 \%)$ patients with CD30- T-cell lymphoma showed $\beta$-catenin positivity, demonstrating a significant association $(P=0.0016)$ between $\beta$-catenin staining and CD30 immunoreactivity (Table 2).

\section{Correlation between $\beta$-Catenin Expression and Large Cell Transformation in Mycosis Fungoides}

Our immunohistochemical results in MF revealed an important association between $\beta$-catenin expression and disease progression $(P=0.00041)$. In particular, we reported that 9 of $13(69 \%)$ patients that developed the morphologic appearance of a large cell lymphoma showed a strong $\beta$-catenin staining. More importantly, this positivity was predominantly seen in large transformed cells. In contrast, only 2 of $22(9 \%)$ of low-grade $\mathrm{MF}$ expressed $\beta$-catenin (Table 3). 
Table 1 Expression of $\beta$-catenin in cutaneous NHL

\begin{tabular}{|c|c|c|c|c|}
\hline Case no. & Sex/age & Diagnosis & $\beta$-catenin+ & Mutation \\
\hline \multicolumn{5}{|c|}{ Primary cutaneous B-cell lymphoma } \\
\hline 1 & $\mathrm{M} / 72$ & DLBCL & 0 & ND \\
\hline 2 & M/39 & DLBCL & 0 & ND \\
\hline 3 & $\mathrm{~F} / 48$ & DLBCL & 0 & ND \\
\hline 4 & $\mathrm{~F} / 67$ & DLBCL & 0 & ND \\
\hline 5 & $\mathrm{M} / 32$ & DLBCL & 0 & ND \\
\hline 6 & $\mathrm{M} / 70$ & DLBCL & 2 & WT \\
\hline 7 & M/69 & DLBCL & 0 & ND \\
\hline 8 & $\mathrm{M} / 59$ & DLBCL & 0 & ND \\
\hline 9 & $\mathrm{M} / 49$ & DLBCL & 0 & ND \\
\hline 10 & $\mathrm{~F} / 55$ & DLBCL & 0 & ND \\
\hline 11 & $\mathrm{M} / 53$ & DLBCL & 0 & ND \\
\hline 12 & $\mathrm{M} / 54$ & DLBCL & 0 & ND \\
\hline 13 & $\mathrm{M} / 53$ & DLBCL & 0 & ND \\
\hline 14 & $\mathrm{M} / 49$ & DLBCL & 0 & ND \\
\hline 15 & $\mathrm{M} / 51$ & DLBCL & 1 & ND \\
\hline 16 & $\mathrm{M} / 41$ & DLBCL & 3 & WT \\
\hline 17 & $\mathrm{M} / 71$ & MZBCL & 3 & WT \\
\hline 18 & $\mathrm{M} / 79$ & MZBCL & 0 & ND \\
\hline 19 & $\mathrm{~F} / 55$ & MZBCL & 0 & ND \\
\hline 20 & $\mathrm{M} / 37$ & FL & 0 & ND \\
\hline 21 & M/63 & FL & 2 & WT \\
\hline 22 & $\mathrm{M} / 83$ & FL & 0 & ND \\
\hline 23 & M/61 & FL & 0 & ND \\
\hline 24 & $\mathrm{M} / 49$ & FL & 0 & ND \\
\hline \multicolumn{5}{|c|}{ Primary cutaneous T-cell lymphoma } \\
\hline 25 & $\mathrm{M} / 50$ & $\mathrm{MF}$ & 2 & WT \\
\hline 26 & $\mathrm{M} / 41$ & $\mathrm{MF}$ & 0 & ND \\
\hline 27 & $\mathrm{~F} / 28$ & $\mathrm{MF}$ & 0 & ND \\
\hline 28 & $\mathrm{M} / 28$ & MF & 0 & ND \\
\hline 29 & $\mathrm{M} / 40$ & MF & 0 & ND \\
\hline 30 & $\mathrm{M} / 72$ & MF & 0 & ND \\
\hline 31 & $\mathrm{M} / 62$ & $\mathrm{MF}$ & 0 & ND \\
\hline 32 & $\mathrm{M} / 27$ & $\mathrm{MF}$ & 0 & ND \\
\hline 33 & $\mathrm{~F} / 74$ & MF & 0 & ND \\
\hline 34 & $\mathrm{M} / 42$ & MF & 0 & ND \\
\hline 35 & $\mathrm{M} / 35$ & $\mathrm{MF}$ & 0 & ND \\
\hline 36 & $\mathrm{~F} / 37$ & $\mathrm{MF}$ & 0 & ND \\
\hline 37 & $\mathrm{M} / 26$ & $\mathrm{MF}$ & 0 & ND \\
\hline 38 & $\mathrm{M} / 70$ & $\mathrm{MF}$ & 1 & ND \\
\hline 39 & $\mathrm{M} / 40$ & $\mathrm{MF}$ & 0 & ND \\
\hline 40 & $\mathrm{M} / 71$ & $\mathrm{MF}^{*}$ & 4 & WT \\
\hline 41 & $\mathrm{M} / 63$ & MF & 0 & ND \\
\hline 42 & $\mathrm{~F} / 68$ & $\mathrm{MF}$ & 0 & ND \\
\hline 43 & $\mathrm{M} / 67$ & $\mathrm{MF}$ & 0 & ND \\
\hline 44 & $\mathrm{M} / 32$ & $\mathrm{MF}$ & 0 & ND \\
\hline 45 & $\mathrm{M} / 44$ & MF & 0 & ND \\
\hline 46 & $\mathrm{~F} / 66$ & $\mathrm{MF}$ & 0 & ND \\
\hline 47 & M/65 & $\mathrm{MF}$ & 0 & ND \\
\hline 48 & M/91 & $\mathrm{MF}^{*}$ & 0 & ND \\
\hline 49 & $\mathrm{~F} / 80$ & $\mathrm{MF}^{* *}$ & 2 & WT \\
\hline 50 & $\mathrm{M} / 38$ & $\mathrm{MF}^{* *}$ & 2 & WT \\
\hline 51 & $\mathrm{~F} / 53$ & $\mathrm{MF}^{* *}$ & 0 & ND \\
\hline 52 & $\mathrm{M} / 38$ & $\mathrm{MF}^{* *}$ & 2 & WT \\
\hline 53 & $\mathrm{M} / 72$ & $\mathrm{MF}^{* *}$ & 0 & WT \\
\hline 54 & $\mathrm{~F} / 71$ & $\mathrm{MF}^{* *}$ & 1 & WT \\
\hline 55 & $\mathrm{~F} / 54$ & $\mathrm{MF}^{* *}$ & 4 & WT \\
\hline 56 & $\mathrm{M} / 37$ & $\mathrm{MF}^{* *}$ & 0 & ND \\
\hline 57 & $\mathrm{~F} / 36$ & $\mathrm{MF}^{* *}$ & 2 & ND \\
\hline 58 & $\mathrm{M} / 28$ & $\mathrm{MF}^{* *}$ & 1 & WT \\
\hline 59 & $\mathrm{~F} / 69$ & $\mathrm{MF}^{* *}$ & 1 & ND \\
\hline 60 & $\mathrm{M} / 52$ & ALCL & 2 & WT \\
\hline 61 & $\mathrm{M} / 56$ & ALCL & 3 & ND \\
\hline 62 & $\mathrm{M} / 52$ & ALCL & 2 & ND \\
\hline 63 & $\mathrm{M} / 27$ & ATCL & 0 & ND \\
\hline 64 & $\mathrm{~F} / 59$ & $\mathrm{NK} / \mathrm{T}$ & 0 & ND \\
\hline 65 & $\mathrm{M} / 62$ & SS & 0 & ND \\
\hline 66 & $\mathrm{M} / 72$ & SS & 1 & WT \\
\hline
\end{tabular}

Table 1 Continued

\begin{tabular}{|c|c|c|c|c|}
\hline Case no. & Sex/age & Diagnosis & $\beta$-catenin+ & Mutation \\
\hline 67 & M/59 & SS & 0 & ND \\
\hline 68 & $\mathrm{~F} / 59$ & SS & 2 & ND \\
\hline 69 & $\mathrm{M} / 48$ & SS & 3 & WT \\
\hline 70 & $\mathrm{M} / 63$ & SS & 0 & ND \\
\hline 71 & M/66 & SS & 3 & WT \\
\hline 72 & $\mathrm{M} / 52$ & SS & 2 & WT \\
\hline 73 & M/86 & SS & 1 & ND \\
\hline 74 & $\mathrm{~F} / 59$ & SS & 4 & WT \\
\hline \multicolumn{5}{|l|}{ Control } \\
\hline 1 & $\mathrm{~F} / 29$ & Dermatitis & 0 & ND \\
\hline 2 & $\mathrm{~F} / 41$ & Dermatitis & 0 & ND \\
\hline 3 & $\mathrm{M} / 60$ & Dermatitis & 0 & ND \\
\hline 4 & $\mathrm{~F} / 60$ & Dermatitis & 0 & ND \\
\hline 5 & M/39 & Dermatitis & 0 & ND \\
\hline 6 & M/66 & Psoriasis & 0 & ND \\
\hline 7 & $\mathrm{M} / 71$ & Psoriasis & 0 & ND \\
\hline 8 & $\mathrm{~F} / 46$ & Eczema & 0 & ND \\
\hline 9 & M/68 & Eczema & 0 & ND \\
\hline 10 & M/65 & Eczema & 0 & ND \\
\hline
\end{tabular}

$\mathrm{DLBCL}=$ diffuse large B-cell lymphoma; $\mathrm{FL}=$ follicular lymphoma; MZBCL = marginal zone B-cell lymphoma; $\mathrm{MF}=$ mycosis fungoides; ALCL $=$ anaplastic large cell lymphoma; $\mathrm{NK}=\mathrm{NK}$-cell lymphoma; ATCL $=$ angiocentric T-cell lymphoma; $S S=$ Sézary Syndrome. ${ }^{*}$ In evolution to a large T-cell lymphoma CD30(-). ${ }^{* *} \operatorname{In}$ evolution to a large T-cell lymphoma CD30+. Staining intensities were classified semi-quantitatively as follows: 4 : strong expression in $75-100 \%$ of the tumor cells; $3: 50-75 \%$; $2: 50-25 \% ; 1: 25-10 \%$ of the tumor cells. $\mathrm{ND}=$ not done; $\mathrm{WT}=$ wild type

\section{Mutational Analysis of $\beta$-Catenin Exon 3}

In order to investigate a possible cause of $\beta$-catenin deregulation in primary cutaneous lymphomas, we performed a mutational analysis in 19 of the 26 samples that exhibited marked accumulation of $\beta$-catenin in the neoplastic lymphoid cells. A portion of exon 3 coding for the GSK-3 $\beta$ phosphorylation consensus region of $\beta$-catenin was selected for analysis because it harbors the majority of $\beta$ catenin mutations identified in other human malignancies. The technique is based on the principle that when heated and then cooled mutated $\beta$-catenin will form secondary conformers different from those seen with WT $\beta$-catenin. These conformers can be detected as an extra or abnormal band when the PCR product is run on a polyacrylamide gel. Aberrant mobility shift, indicating a genetic mutation, was never detected in any of our samples (Figure 2).

\section{Discussion}

In this study, we demonstrated that $\beta$-catenin is expressed by tumor cells in cutaneous lymphoproliferative disorders at various frequencies. Interestingly, mutations of $\beta$-catenin exon 3 were not detected in any of the analyzed samples, indicating that while deregulation of $\beta$-catenin expression is frequent, mutations in its gene are rare in cutaneous lymphomas. 
a
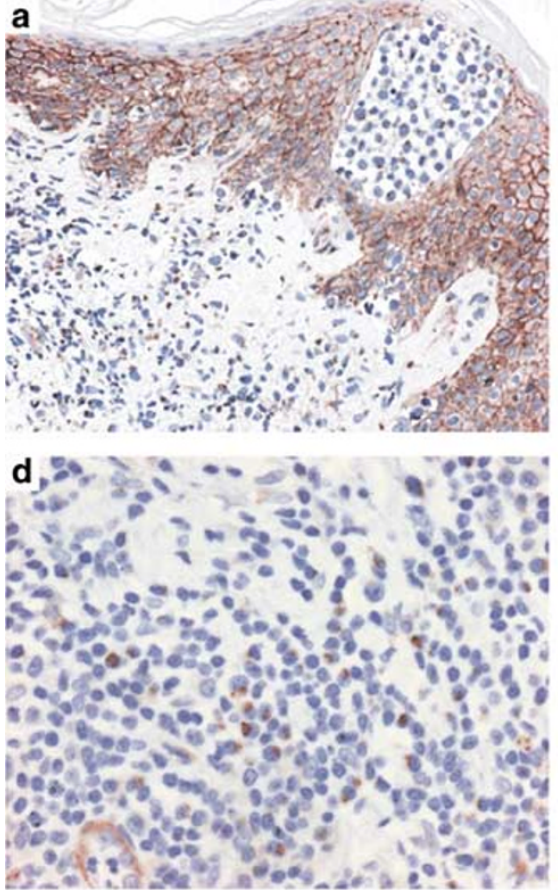

g.

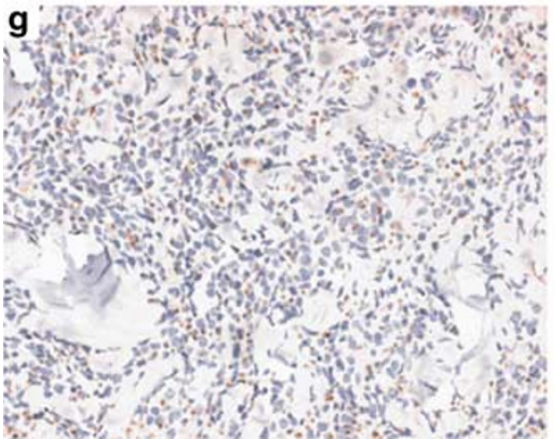

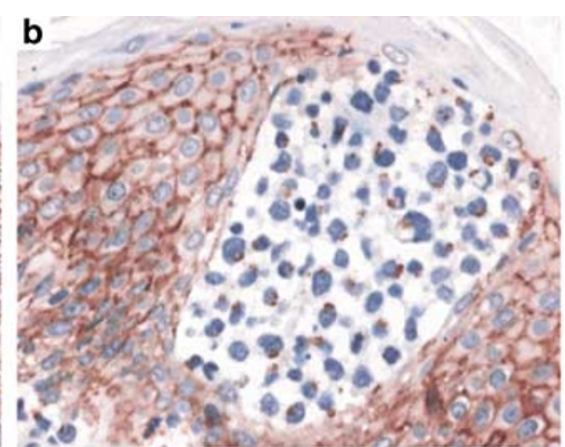
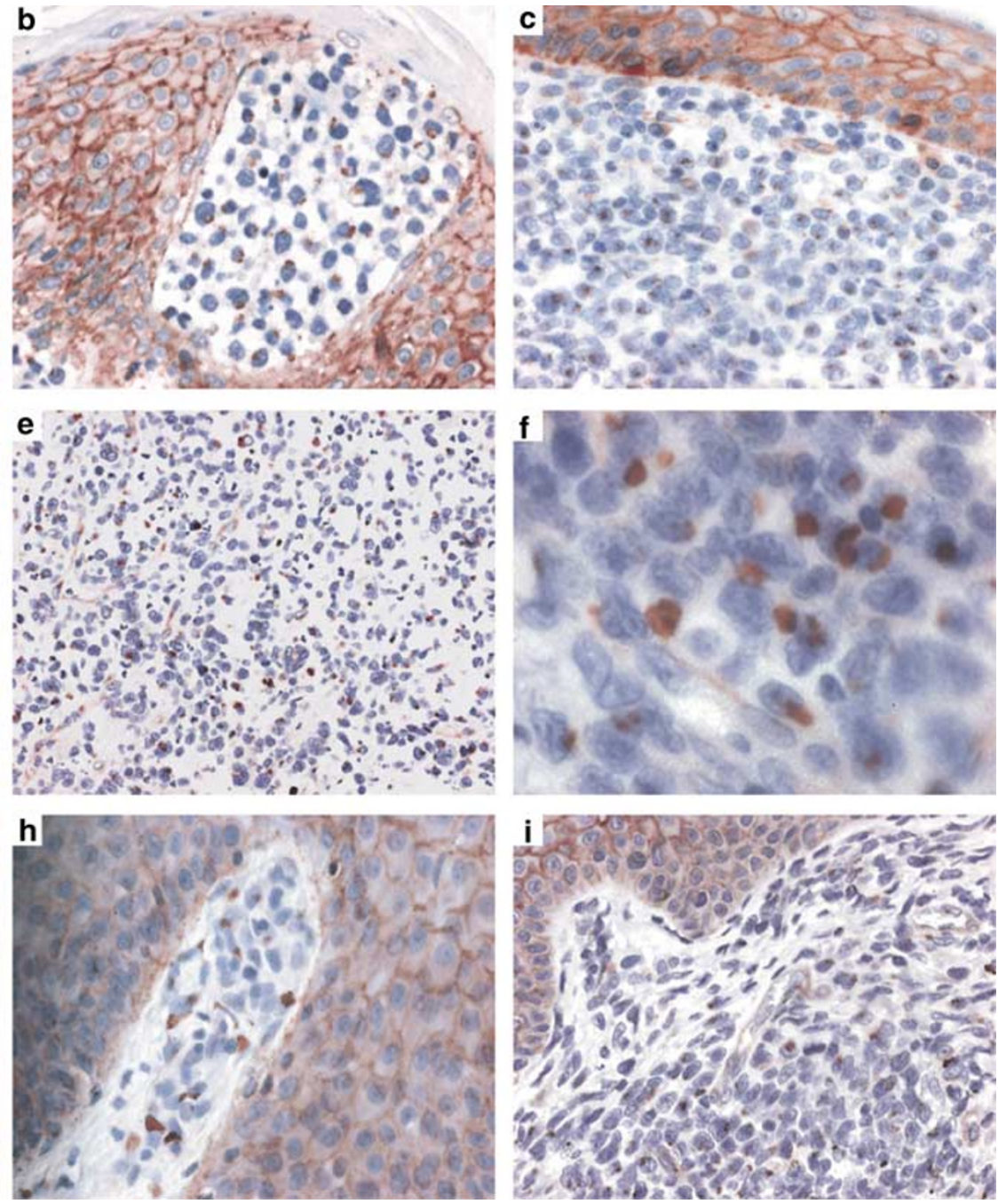

Figure 1 Representative immunohistochemistry analysis of $\beta$-catenin in human primary cutaneous lymphomas. (a) Sézary Syndrome demonstrating $\beta$-catenin positive cells in the dermal and epidermal infiltration of neoplastic lymphoid cells. (b) Same case of SS as (a) at high magnification showing strong expression in Pautrier microabscess. (c) Large B-cell lymphoma. (d-f) Three different cases of anaplastic large cell lymphoma. (h) A case of Mycosis fungoides. (g-i) Mycosis fungoides in large cell transformation.

Table 2 Significant relationship between $\beta$-catenin and CD30 expression in T-cell lymphoma

\begin{tabular}{llrrr}
\hline & & \multicolumn{2}{c}{ CD30 } & Total \\
\cline { 3 - 4 } & & - & + & \\
\hline$\beta$-Catenin & - & 26 & 3 & 29 \\
& + & 10 & 11 & 21 \\
Total & & 36 & 14 & 50 \\
\hline
\end{tabular}

Normal resting peripheral blood mononuclear cells do not contain detectable levels of $\beta$-catenin protein. In contrast, neoplastic lymphoid cells showed a cytoplasmic distribution with a particular perinuclear dot-like aspect. Our observation suggests the possibility that the cellular localization of $\beta$-catenin is in the Golgi apparatus. The absence of $\beta$ -
Table 3 Significant relationship between $\beta$-catenin expression and large cell transformation in Mycosis fungoides

\begin{tabular}{lrrrr}
\hline & & \multicolumn{2}{c}{$M F$} & Total \\
\cline { 3 - 4 } & & LTC- & LTC+ & \\
\hline \multirow{2}{*}{$\beta$-Catenin } & - & 20 & 4 & 24 \\
\multirow{2}{*}{ Total } & + & 2 & 9 & 11 \\
& & 22 & 13 & 35 \\
\hline
\end{tabular}

$\mathrm{MF}=$ mycosis fungoides; $\mathrm{LTC}=$ large $\mathrm{T}$ cell.

catenin in the nucleus correlates with no detectable expression of target genes for $\beta$-catenin/Tcf-induced transcription such as cyclin D1 (data not shown). The absence of nuclear distribution of $\beta$-catenin could be correlated with the loss of expression of lymphoid enhancer factor-1 (LEF-1) and T-cell factor-1 (TCF-1) in the neoplastic cells. TCF-1 and 

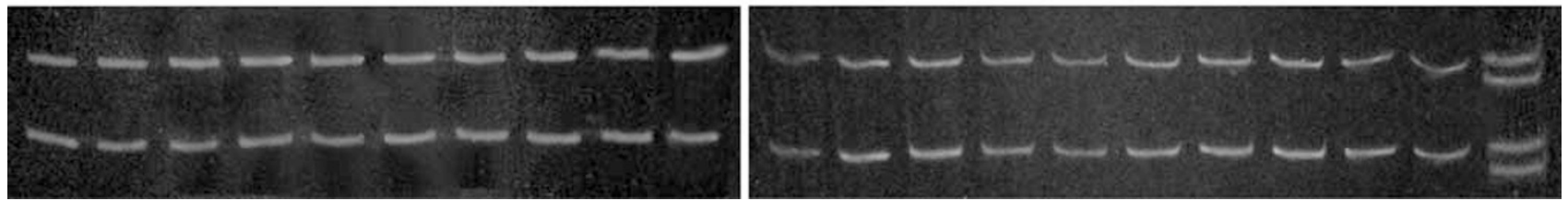

Figure 2 'Cold' single-strand conformation polymorphism analysis of $\beta$-catenin exon 3 in tissue of cutaneous lymphomas. No mobility shifted band was observed compared to human genomic DNA (HG). A mutant carries single base substitution was used to control the migration of aberrant bands compared with wild-type bands (C).

LEF-1 are expressed in thymocytes and mature T cells in mice and human, LEF-1 is also expressed in B-cell precursors, but not in mature B cells. ${ }^{23,24}$ When $\beta$-catenin is absent, the transcription factor TCF-1/LEF-1 acts in the nucleus as a transcriptional repressor interacting with the corepressors (TLE/Groucho and/or CtBP) of the target gene promoters. ${ }^{25}$

Actually, it has been previously reported that $\beta$-catenin nuclear retention is mediated by the LEF-1/TCF-1 transcription factors. ${ }^{26} \beta$-Catenin protein contains no recognizable nuclear localization signal (NLS) and it was proposed that $\beta$-catenin distribution is determined by its interaction with APC or by anchorage to LEF-1/TCF-1 in the nucleus or to cadherin at junctions. Dorfman and coworkers found that TCF-1 and LEF-1 in peripheral T-cell lymphomas are expressed in a coordinate manner, and that this expression correlates with that of the marker of Th1 T-cell activation. In contrast, cases of peripheral T-cell lymphomas expressing marker of Th2 T-cell activation failed to exhibit staining for LEF-1 and TCF-1. ${ }^{27}$ Several studies have suggested that $\mathrm{MF}$ in large cell transformation, primary cutaneous anaplastic large cell lymphomas and Sézary Syndrome correlate with a specific Th2 cytokines pattern subtype and that, in contrast, primary cutaneous T-cell lymphomas CD30-, MF and angiocentric lymphoma express the Th1 differentiation-associated marker. ${ }^{28-30}$ It is interesting to note that our $\beta$-catenin positive cases are mainly Sézary Syndrome, anaplastic large cell lymphomas and MF in large-cell transformation, which are forms of T-cell lymphomas with aggressive behavior and Th2 profile. One could to explain the absence of $\beta$-catenin in the nucleus with the loss of LEF-1 and TCF-1 expression, a finding also reported in Th2 subtypes. It remains to be explained why $\beta$-catenin deregulation occurs preferentially in Th2 subtype of T-cell lymphomas.

Mutations of $\beta$-catenin exon 3 were not detected in any of the analyzed samples indicating that deregulation of $\beta$-catenin signaling may be caused by other mechanisms. These findings are consistent with similar studies in other human tumors, in which $\beta$-catenin accumulation was a frequent event but $\beta$-catenin mutations were infrequent. ${ }^{31,32}$ The role of many proteins that work in regulating $\beta$-catenin including Axin, Axin2, GSK-3 $\beta$,
$\beta$-TrCP, PP2a and FRAT (frequently rearranged in advanced T-cell lymphomas) are currently being investigated. Preliminary date show wild-type Axin2 in most cases. However, we cannot exclude that there is an increase of $\beta$-catenin transcript and of the amount of the protein produced. This point is being tested on established and primary cell lines.

In summary, in our study, we found $\beta$-catenin expression in neoplastic tumor cells in 26 of 74 $(35 \%)$ cases of primary cutaneous lymphoma, but unlike previous studies concerning other human tumors, we did not see any nuclear activity of the protein. The deregulation of $\beta$-catenin, that is a common occurrence in cutaneous lymphomas, appears to correlate with CD30 expression. CD30 is involved in the regulation of apoptosis and proliferation of activated lymphoid cells suggesting that the outcome of CD30 engagement may depend on the target cell, its state of differentiation, its transformation status and environmental cofactors. ${ }^{33}$ The expression of this molecule can be induced on normal peripheral blood B- and T cells by mitogens and viruses, indicating that CD30 represents a differentiation antigen whose expression is associated with activation of lymphoid cells. $\beta$-Catenin activation has a positive role in the control of T-cell development and it is possible to speculate that the coexpression of $\beta$-catenin and CD30 might be a signal of the lost proliferative control by lymphoid cells. Even if there is no evidence of the usefulness of $\beta$-catenin accumulation as a clinical prognostic marker because it is present in both low-and highgrade lymphomas, it may be relevant within the MF group. This point will be proven after a longer follow-up.

\section{Acknowledgements}

We wish to thank $\mathrm{Dr} \mathrm{D}$ Castiglia for providing the exon 3 mutant sample, and S Simonaro and A Bucci for technical assistance.

\section{References}

1 Abd-el-Baki J, Stefanato C, Koh HK, et al. Early detection of cutaneous lymphoma. Oncology 1998;10: 1521-1530. 
2 Pimpinelli N, Santucci M, Mori M, et al. Primary cutaneous B-cell lymphoma: A clinically homogeneous entity? J Am Acad Dermatol 1997;37: 1012-1016.

3 Burg G, Dummer R, Haeffner A, et al. From inflammation to neoplasia: mycosis fungoides evolves from reactive inflammatory conditions (lymphoid infiltrates) transforming into neoplastic plaques and tumor. Arch Dermatol 2001;137:949-952.

4 Provost E, Rimm DL. Controversies at the cytoplasmic face of the cadherin-based adhesion complex. Curr Opin Cell Biol 1999;11:567-572.

5 Miller JR, Hocking AM, Brown JD, et al. Mechanisms and function of signal trasduction by the Wnt/betacatenin and Wnt/Ca+ pathways. Oncogene 1999;18: 7860-7872.

6 Barker N, Clevers H. Catenins, Wnt signaling and cancer. Bioassays 2000;22:961-965.

7 Polakis P. The oncogenic activation of beta-catenin. Curr Opin Genet Dev 1999;9:15-21.

8 Aberle H, Bauer A, Stappert J, et al. beta-catenin is a target for the ubiquitin-proteosome pathway. EMBO J 1997;16:3797-3804.

9 Kikuchi A. Regulation of $\beta$-catenin signaling in the Wnt pathway. Biochem Biophys Res Commun 2000; 268:243-248

10 Omer CA, Miller PJ, Diehl RE, et al. Identification of Tcf4 a residues involved in high-affinity beta-catenin binding. Biochem Biophys Res Commun 1999;256: 584-590.

11 Behrens J, Von Kries JP, Kuhl M, et al. Functional interaction of beta-catenin with the transcription factor LEF-1. Nature 1996;382:638-642.

12 He TC, Sperks AB, Rago C, et al. Identification of c-MYC as a target of the APC pathway. Science 1998;281:1509-1512.

13 Testu O, McCormick F. Beta-catenin regulates expression of cyclin D1 in colon carcinoma cells. Nature 1999;398:422-426.

14 Crawford HC, Fingleton BM, Rudolph-Owen LA, et al. The metalloproteinase matrilysin is a target of betacatenin transactivation in intestinal tumors. Oncogene 1999;18:2883-2891.

15 Huang H, Mahler-Araujo B, Sankila A, et al. APC mutations in sporadic medulloblastomas. Am J Pathol 2000;156:433-437.

16 Satoh S, Daigo Y, Furukawa Y, et al. AXIN1 mutations in hepatocellular carcinomas, and growth suppression in cancer cells by virus-mediated transfer of AXIN1. Nat Genet 2000;24:245-250.

17 Polakis P. Wnt signaling and cancer. Genes Dev 2000;14:1837-1851.

18 Ioannidis $\mathrm{V}$, Beermann $\mathrm{F}$, Clevers $\mathrm{H}$, et al. The $\beta$ catenin-Tcf-1 pathway ensures $\mathrm{CD} 4^{+} \mathrm{CD} 8^{+}$thymocyte survival. Nat Immun 2001;2:691-697.

19 Gounari F, Aifantis I, Khazaie K, et al. Somatic activation of $\beta$-catenin bypasses pre-TCR signaling and TCR selection in thymocyte development. Nat Immun 2001;2:863-869.

20 Van de Wetering $M$, de Lau W, Clevers H. Wnt signaling and lymphocyte development. Cell 2002;109: S13-S19.

21 Tsutsui J, Moriyama M, Arima N, et al. Expression of cadherin-catenin complexes in human leukemia cell lines. J Biochem 1996;120:1034-1039.

22 Chung EJ, Hwang SG, Nguyen P, et al. Regulation of leukemic cell adhesion, proliferation, and survival by $\beta$-catenin. Blood 2002;100:982-990.

23 Reya T, O’Riordan M, Okamura R, et al. Wnt signaling regulates B lymphocyte proliferation througt a LEF-1 depentent mechanism. Immunity 2000;13:15-24.

24 Christian LS, Sims PV, Gold MR. The B cell antigen receptor regulates the transcriptional activator $\beta$ catenin via protein kinase C-mediated inhibition of glycogen synthase kinase-3. J Immunol 2002;169: 758-769.

25 Van Es JH, Barker N, Clevers H. You Wnt some, you lose some: oncogenes in the Wnt signaling pathway. Curr Opin Genet Dev 2003;13:28-33.

26 Simcha I, Shtutman M, Salomon D, et al. Differential nuclear translocation and transactivation potential of beta-catenin and plakoglobin. J Cell Biol 1998;141: 1433-1448.

27 Dorfman DM, Greisman HA, Shahsafaei A. Loss of expression of the $\mathrm{Wnt} / \beta$-catenin-signaling pathway transcription factors Lymphoid Enhancer Factor-1 (LEF-1) and T-cell factor-1 (TCF-1) in a subset of peripheral T-cell lymphomas. Am J Pathol 2003;162: 1539-1544.

28 Jones D, O’Hara C, Kraus MD, et al. Expression pattern of T-cell-associated chemokine receptors and their chemokines correlates with specific subtypes of T-cell non-Hodgkin lymphoma. Blood 2000;96: 685-690.

29 Dorfman DM, Shahsafaei A. CD69 expression correlates with expression of other markers of Th1 T cell differentiation in peripheral $\mathrm{T}$ cell lymphomas. Hum Pathol 2002;33:330-334.

30 Vermeer MH, Tensen CP, van der Stoop PM, et al. Absence of Th2 cytokine messanger RNA expression in CD30 negative primary cutaneous large T-cell lymphomas. Arch Dermatol 2001;137:901-905.

31 Sugimachi K, Taguchi K, Aishima S, et al. Altered expression of $\beta$-catenin without genetic mutation in intrahepatic cholangiocarcinoma. Mod Pathol 2001;14:900-905.

32 Haydon RC, Deyrup A, Ishikawa A, et al. Cytoplasmic and/or nuclear accumulation of the $\beta$-catenin protein is a frequent event in human osteosarcoma. Int J Cancer 2002;102:338-342.

33 Gruss HJ, Boiani N, Williams DE, et al. Pleiotropic effects of the CD30 ligand on CD30-expressing cells and lymphoma cell lines. Blood 1994;83: 2045-2056. 